\title{
Mass spectrometry with paper spray ionization in analysis of the Arrabidaea chica
}

\section{leaf tea}

\author{
Espectrometria de massas com ionização por paper spray na análise do chá das follhas de
} Arrabidaea chica

Espectrometría de masas con ionización por paper spray en el análisis del té de hojas de Arrabidaea chica

Vinícius Moura Andrade

ORCID: https://orcid.org/0000-0002-2098-6546 Centro Federal de Educação Tecnológica de Minas Gerais, Brazil E-mail: viniciusmourandrade@ yahoo.com.br

Gustavo Henrique Cassemiro de Souza ORCID: https://orcid.org/0000-0003-2347-6346 Centro Federal de Educação Tecnológica de Minas Gerais, Brazil E-mail: gustacassemiro@gmail.com

Fátima de Cássia Oliveira Gomes ORCID: https://orcid.org/0000-0001-7358-7154 Centro Federal de Educação Tecnológica de Minas Gerais, Brazil E-mail: fatimaog@ cefetmg.br

Ana Maria de Resende Machado ORCID: https://orcid.org/0000-0002-1587-5024 Centro Federal de Educação Tecnológica de Minas Gerais, Brazil E-mail: anamariaderesendemachado@gmail.com

Ildefonso Binatti

ORCID: https://orcid.org/0000-0002-0454-0026 Centro Federal de Educação Tecnológica de Minas Gerais, Brazil E-mail: ibinatti@cefetmg.br

Cleverson Fernando Garcia

ORCID: https://orcid.org/0000-0001-9354-1401 Centro Federal de Educação Tecnológica de Minas Gerais, Brazil E-mail: cleverson@ cefetmg.br

David Lee Nelson

ORCID: https://orcid.org/0000-0001-7435-3675 Universidade Federal dos Vales de Jequitinhonha e Mucuri, Brazil E-mail: dleenelson@gmail.com

\begin{abstract}
The species Arrabidaea chica (Humb. \& Bonpl.) B. Verl. (Bignoniaceae) is a plant native to tropical forests, popularly known as pariri or crajiru, and it is widely used in folk medicine to treat inflammatory diseases, anemias, skin diseases and to assist in the treatment of leukemia. Because of the widespread use of the plant, concern with its quality and effectiveness is fundamental. This study demonstrates the application of mass spectrometry with ionization by paper spray (PS-MS) as a chemical characterization method to evaluate the presence of the active principles in teas prepared by infusion from commercial samples of the medicinal plant Arrabidaea chica by infusion. The analyses of the samples were performed in two periods: 24 hours and 15 days after the preparation of the teas. Compounds referring to the class of substances 3-deoxythocyanidins were detected without any pre-treatment of the sample or chromatographic separation to provide valuable information for the evaluation and quality control of this product. Significant changes in the $\mathrm{m} / \mathrm{z}$ signals of greater intensity, referring to the class of 3-deoxythocyanidins, were observed in the mass spectra, and multivariate analysis corroborated the degradation of this class of substances with time, resulting in a probable loss of the quality and effectiveness of the tea.
\end{abstract}

Keywords: Medicinal plants; Arrabidaea chica; Quality control; Paper spray.

\section{Resumo}

A espécie Arrabidaea chica (Humb. \& Bonpl.) B. Verl. (Bignoniaceae) é uma planta nativa das florestas tropicais, popularmente conhecida como pariri ou crajiru, amplamente utilizada na medicina popular no tratamento de doenças inflamatórias, anemias, enfermidades da pele e auxiliar no tratamento de leucemia. Devido ao uso difundido da planta é fundamental a preocupação com sua qualidade e eficácia. Este estudo demonstra a aplicação da Espectrometria de 
Massas com a Ionização por Paper Spray (PS-MS) como uma metodologia de caracterização química para avaliar a presença dos princípios ativos presentes nos chás obtidos por infusão de amostras comerciais da planta medicinal Arrabidaea chica obtidos por infusão. As análises das amostras foram realizadas em dois períodos: 24 horas e 15 dias após o preparo dos chás. Foram detectados compostos referentes à classe de substâncias 3 desoxiantocianidinas sem qualquer pré-tratamento da amostra ou separação cromatográfica, fornecendo informações valiosas para a avaliação e controle de qualidade deste produto. Alterações significativas nos sinais $\mathrm{m} / \mathrm{z}$ de maior intensidade, referentes à classe da 3 desoxiantocianidinas, foram observadas nos espectros de massas. As análises multivariadas dos dados, por sua vez, corroboraram a degradação desta classe de substâncias como o decorrer do tempo e, consequentemente, uma provável perda da qualidade e eficácia do chá.

Palavras-chave: Plantas Medicinais; Arrabidaea chica; Controle de qualidade; Paper Spray.

\section{Resumen}

La especie Arrabidaea chica (Humb. \& Bonpl.) B. Verl. (Bignoniaceae) es una planta originaria de los bosques tropicales, conocida popularmente como pariri o crajiru, y se usa ampliamente en la medicina popular para tratar enfermedades inflamatorias, anemia, dermatosis y para ayudar a tratar las leucemias. Debido al amplio uso de la planta, la preocupación por su calidad y efectividad es fundamental. Este estudio demuestra la aplicación de la Espectrometría de Masas de Ionización por Paper Spray (PS-MS) como método de caracterización química para evaluar la presencia de principios activos en tés preparados por infusión a partir de muestras comerciales de la planta medicinal Arrabidaea chica por infusión. Los análisis de las muestras se realizaron en dos períodos: 24 horas y 15 días después de la preparación del té. Los compuestos que se refieren a la clase de sustancias 3-desoxitocianidina se detectaron sin ningún pretratamiento o separación cromatográfica de la muestra para proporcionar información valiosa para la evaluación y el control de calidad de este producto. Se observaron cambios significativos en las señales $\mathrm{m} / \mathrm{z}$ de mayor intensidad, que se refieren a la clase de 3-desoxitocianidinas. El análisis multivariado, a su vez, corroboraron la degradación de esta clase de sustancias a lo largo del tiempo, resultando en una probable pérdida de la calidad y eficacia del té.

Palabras clave: Plantas medicinales; Arrabidaea chica; Control de calidad; Paper Spray.

\section{Introduction}

The species Arrabidaea chica (Humb. \& Bonpl.) B. Verl. belongs to the family Bignoniaceae. It is distributed mainly in the tropical regions of South America and Africa. In Brazil, it does not have a unique habitat, being found in several regions, mainly in the Amazon (Medeiros et al., 2011). The plant is popularly known as crajiru (Amazonas), carajiru, pariri (Pará), and vine-cross, among other names (Ferreira et al., 2013).

According to folk medicine, the leaves of Arrabidaea chica have anti-inflammatory, healing, anti-anemic and astringent properties. They are used to fight hemorrhage, leukemia and skin diseases (Kalil Filho et al., 2000; Behrens et al., 2012). The widespread use of the plant in medicine and its pharmacological activities has aroused the interest of several researchers. Thus, the standardization of its extracts through studies of its chemical profile is essential (Behrens et al., 2012; Schiozer et al., 2012).

Arrabidaea chica is characterized by the occurrence of the class of deoxyanthocyanidins, which are responsible for conferring the reddish color characteristic of its extracts (Schioz et al., 2012). Through electrospray ionization mass spectrometry (ESI-MS), some authors have identified and characterized four chemical markers belonging to the 3deoxyanthocyanidin class: 6,7-dihydroxy-5,4'-dimethoxyflavylium (carajurine) (I), 6,7,4'-trihydroxy-5-methoxyflavylium (carajurone) (II), 6,7,3'-trihydroxy-5,4'-dimethoxyflavylium (III) and 6,7,3',4'-tetrahydroxy-5-methoxyflavylium (IV) (Zorn et al., 2001; Schiozer et al., 2012; Mafiolletti et al., 2013; Taffarello et al., 2013).

Ambient ionization is an area of mass spectrometry that has emerged quickly in several methods, all aiming at direct and rapid sampling of analytes in complex samples with the minimum of previous treatment in their ambient state (Liu et al., 2010). Recently, Wang and collaborators (2010) described a new technique of ambient ionization called mass spectrometry with paper spray ionization (PS-MS).

The PS-MS ionization method is based on the generation of analyte ions by applying a high voltage on a chromatographic paper triangle with a small volume $(<10 \mu \mathrm{L})$ of the sample, which is performed at the entrance of a mass 
spectrometer. The samples are loaded onto the paper with the addition of an appropriate solvent, which was usually methanol. The applied potential difference causes the formation of a fine spray of solvent droplets with the analyte on the tip of the paper because of the greater accumulation of charges (Liu et al., 2010).

In the literature, the method has been approached in different matrices such as in the analysis of drugs in biological fluids (blood and urine) (Liu et al., 2010), analysis of natural products such as plants and teas (Liu et al., 2011; Deng and Yang, 2013), forensic sciences (Ferreira et al., 2015), food (Soparawalla et al., 2011; Zhang et al., 2012; Garret et al., 2013) and discrimination of microorganisms (Hamid et al., 2014). This work sought to evaluate and compare the chemical fingerprint profile of teas obtained by infusing Arrabidaea chica leaves from different commercial samples and to verify the influence of time on its composition using mass spectrometry with PS-MS.

\section{Methodology}

The work corresponded to laboratory activities, with the extraction by infusion of pariri leaves and the identification of its constituents, after 24 hours and 15 days of extraction, as well as the study of grouping these extracts, considering the time and the bioactive compounds present. Furthermore, it was characterized as a descriptive research because, according to Oliveira (2011), it took into account the observation, registration and analysis of the objects of study and their relationship with other phenomena.

\subsection{Plant material}

A total of fourteen different samples from the Arrabidaea chica plant were purchased from different commercial establishments in Belo Horizonte (MG) and the metropolitan region in the period from February to March 2018.

\subsection{Preparation of extracts}

The extracts were prepared by infusing $1.0 \mathrm{~g}$ of the dried leaves of the samples of Arrabidaea chica in $30 \mathrm{~mL}$ of distilled water at $100{ }^{\circ} \mathrm{C}$ for a period of one hour. The extracts were filtered and stored in amber bottles under refrigeration at 6 to $10^{\circ} \mathrm{C}$

\subsection{Mass Spectrometry with Paper Spray Ionization}

For the paper spray ionization analysis, the chromatographic filter papers were cut into triangles $(10 \mathrm{~mm}$ high and 10 $\mathrm{mm}$ base) and attached to a metal alligator clip at $5 \mathrm{~mm}$ from the mass spectrometer source. About $10 \mu \mathrm{L}$ of the tea samples were transferred directly to the paper triangle and left to dry at room temperature. Then, $10 \mu \mathrm{L}$ of methanol were added and voltage $(3 \mathrm{kV})$ was applied to obtain the mass spectra. The analyzes were performed on teas prepared $24 \mathrm{~h}(\mathrm{~A})$ and 15 days (B) after the extracts were prepared.

\subsection{Instrumentation}

All mass spectra were obtained using a Thermo Fisher LCQ FLEET mass spectrometer with a low-resolution ion trap mass analyzer, operating in the positive ion mode. The ionization source was built in the laboratory with a three-dimensional movement to adjust the paper with the mass spectrometer input. The spray voltage was adjusted to $3 \mathrm{kV}$, the capillary temperature was adjusted to $275^{\circ} \mathrm{C}$ and a $40 \mathrm{~V}$ potential, and the potential of the lenses was $120 \mathrm{~V}$. For PS-MS, mass spectra were acquired in positive ion mode over $\mathrm{m} / \mathrm{z}$ range $250-350$. 


\subsection{Multivariate statistical analysis}

The differentiation of the extracts was achieved through Principal Component Analysis (PCA) and Hierarchical Cluster Analysis (HCA). The data were processed in the Minitab 19.2 software. A data matrix with 28 lines (14 commercial samples in periods A and B) and 20 columns (the relative intensities values of the most abundant mass spectra signals) was used. The PCA was performed using a covariance matrix, and the scores of the main components (cumulative eigenvalue greater than $80 \%$ ) were used for the construction of the dispersion graph to evaluate the possible groupings of the commercial samples. In turn, HCA was performed using the Euclidean distance measurement, non-standard data and the centroid linkage method. The respective dendrogram was evaluated for possible groupings of the commercial samples.

\section{Results and Discussion}

The choice for the positive ion mode in the analyses was based on the cationic characteristic of the 3deoxyanthocyanidins (1-4). The ions $\mathrm{m} / \mathrm{z} 285,299,301$ and 315 were identified in the sample of $A$. chica in previous analyses by ESI-(+)-MS (Schiozer et al. 2012, Mafiolletti et al., 2013, Taffarello et al., 2013). In addition to these four substances, Cabral (2010) detected the presence of other anthocyanidins though the peaks of $\mathrm{m} / \mathrm{z} 271,287,303,317$ and 319 through studies using ESI(+) MS/MS. However, it was not possible to define the identity of each of these substances because of the wide variety of structural isomers in this class of compounds.

In our study, the analysis of the spectra of PS-MS obtained from the extracts of the samples of A. chica made 24 hours after preparation (Figure 1), showed little difference in the chemical profile of the samples. A similarity in the intensity of the ions $\mathrm{m} / \mathrm{z} 285,299,301$ and 315, corresponding to the 3-deoxyanthocyanidins, was observed: 6,7,4'-trihydroxy-5methoxyflavylium (carajurone), 6,7-dihydroxy-5,4'-dimethoxyflavylium (carajurine), 6,7,3'-trihydroxy-5,4'dimethoxyflavylium, 6,7,3',4'-tetrahydroxy-5-methoxyflavylium, (I to IV), respectively. Lesser intensity signals m/z 271, 287, 303, 317, and 319 were also detected in all the samples analyzed under this condition.

Figure 1. Representative spectrum obtained in the analysis by PS-MS 24 hours after preparation of the tea.

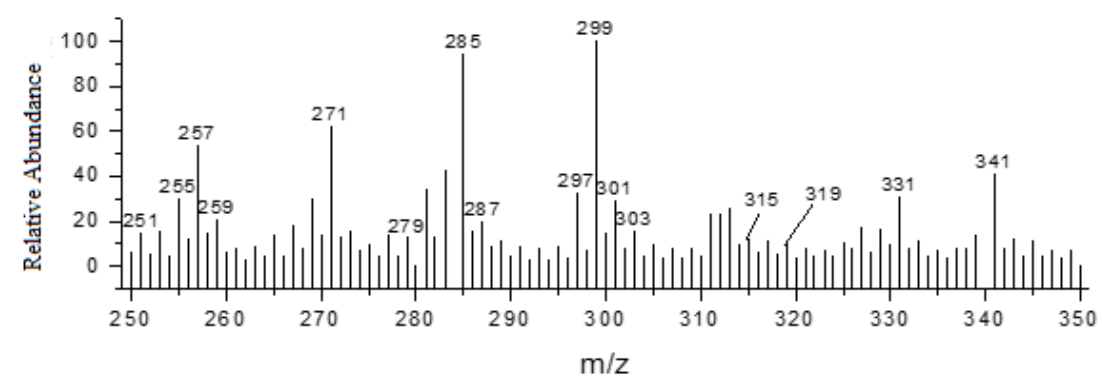

Source: Authors.

For the PS-MS analysis performed 15 days after the preparation of the extracts of A. chica, it was found that, even though all the anthocyanidins were present, the intensity of the signals had changed. The signal of greatest intensity was observed for the ion at $\mathrm{m} / \mathrm{z} 259$ (samples 02, 10 and 12) (Figure 2-a); m/z 271 (samples 01, 06, 07, 11, and 13) (Figure 2-b); m/z 285 (samples 08 and 09) (Figure 2-c) and m/z 299 (samples 03, 04, 05, and 14) (Figure 2-d). 
Figure 2. Representative spectra obtained in the analyses by PS-MS after the preparation of $A$. chica leaf teas: (a) sample 02, (b) sample 13, (c) sample 09 and (d) sample 05.

(a)

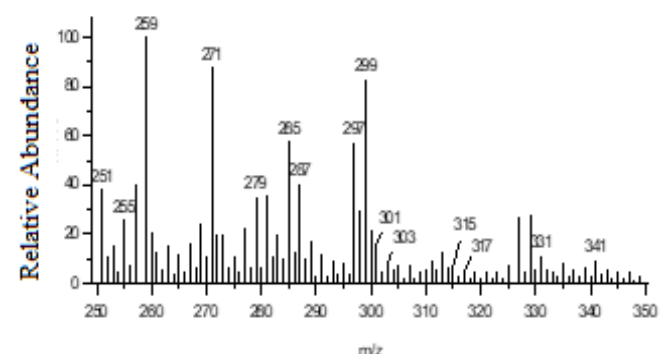

(c)

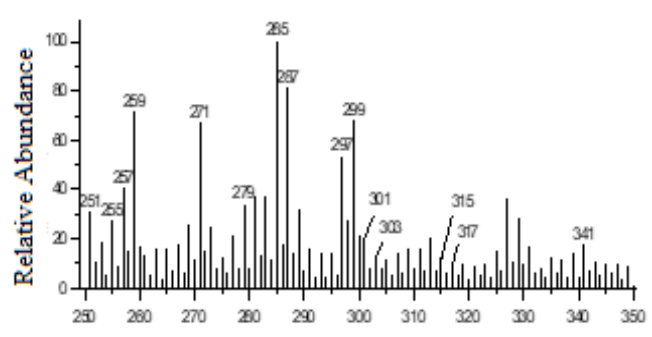

(b)

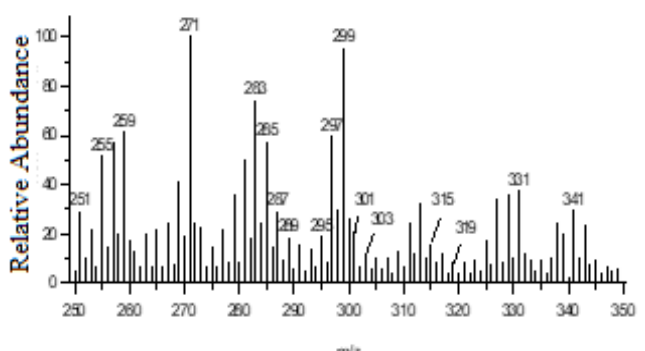

(d)

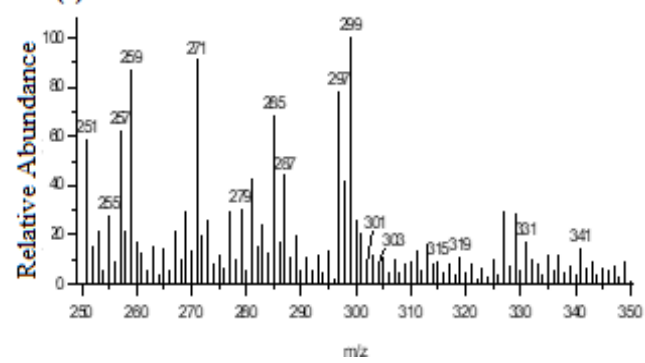

Source: Authors.

These differences can be explained by the degradation of anthocyanins present in A. chica teas over time. Several factors such as $\mathrm{pH}$, storage temperature, structure, concentration, light, presence of oxygen, solvents, enzymes, proteins and metal ions affect the stability of this class of compounds (Castañeda-Ovando et al., 2009).

The use of multivariate analysis of the A. chica extracts was able to grouped the samples based on the differences in the spectra: 24 hours after (Samples A) and 15 days after (Samples B). The Principal Component Analysis with covariance matrix was able to explain $86.3 \%$ of the total data variability. The Figure 3 represents the first two components because the representation in three dimensions does not include new behaviors.

Figure 3. PCA scores for m/z (PS-MS) signals from samples A and B of A. chicai.

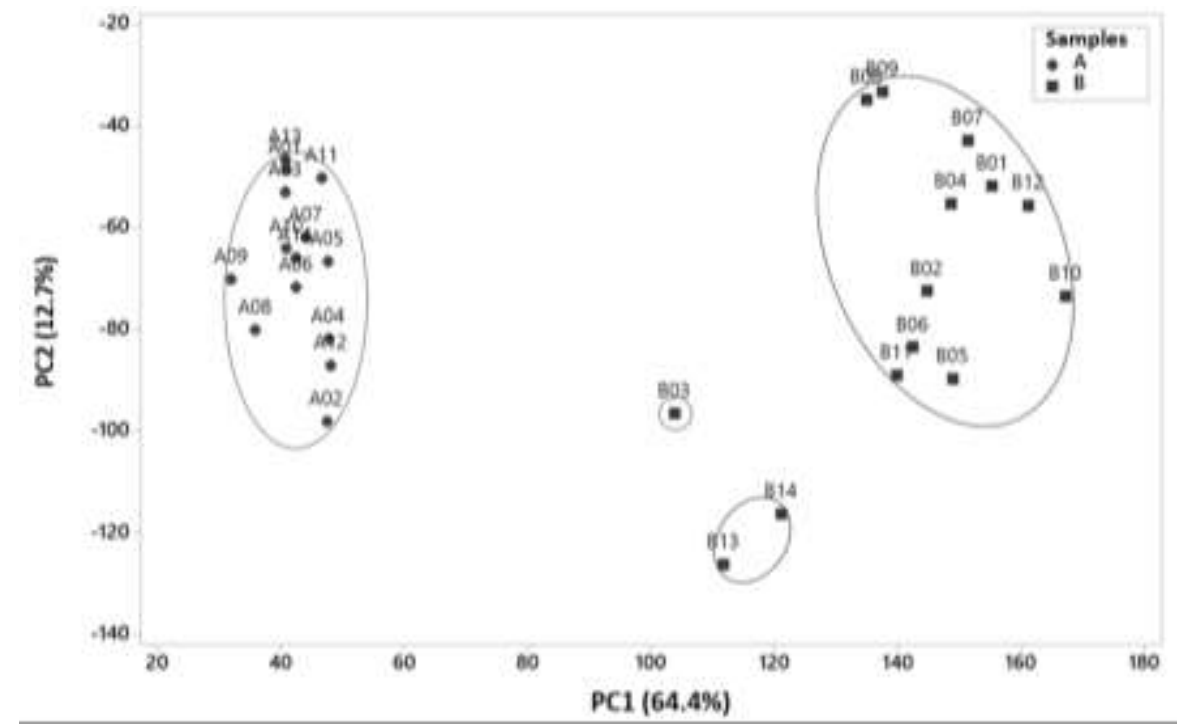

Source: Authors.

The presence of four groups can be seen in Figure 3, where samples A are organized in a single group (greater 
homogeneity). B samples, in turn, were characterized in three groups: 1) B03, 2) B13 and B14 and 3) B01, B02, B04, B05, B06, B07, B08, B09, B10, B11 and B12.

Based on the factorial loads (Figure 4), the sample A profile is a consequence mainly of lower relative abundances of the ions $\mathrm{m} / \mathrm{z} 287,259,279,251$ and 271 and higher relative abundances of the ions $\mathrm{m} / \mathrm{z} 341$ and 299. The group of samples B13 and B14 stood out for exhibiting high relative abundances of the ions m/z 271, 297, 255, 299 and 257, and the sample B03 for the low relative abundances of $\mathrm{m} / \mathrm{z} 285$ and 287 and high relative abundances of $\mathrm{m} / \mathrm{z} 271,297$ and 299. The samples B remaining group was characterized by having high relative abundances of the ions $\mathrm{m} / \mathrm{z}$ 251, 259, 271, 279 and 287.

Figure 4. Factor loadings of the m/z (PS-MS) signals from samples A and B of A. chica.

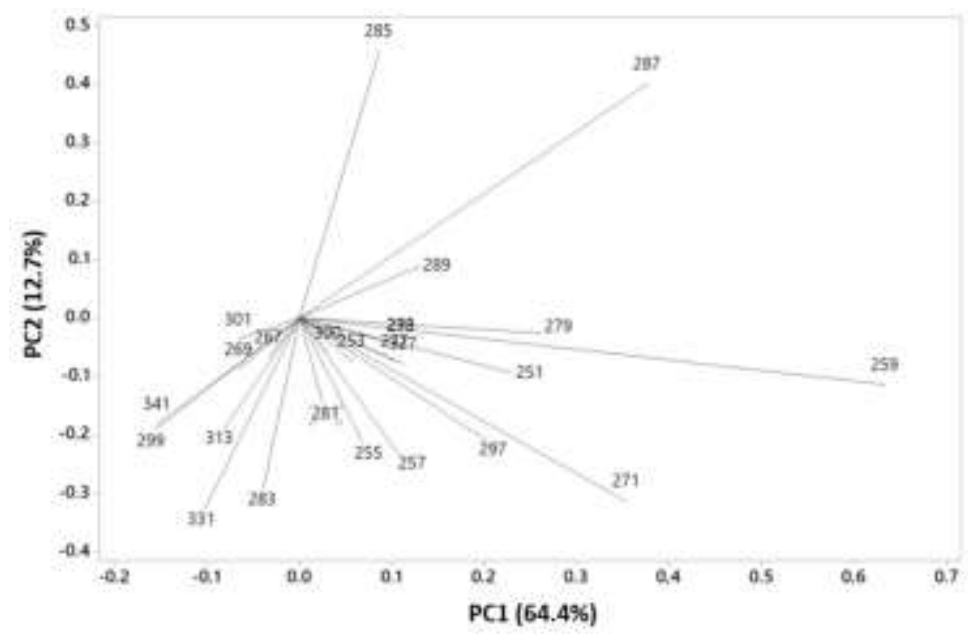

Source: Authors.

Cluster analysis (Figure 5) was also performed, and the same grouping was observed for the centroid link method with Euclidean distance measurement, considering the original non-standard data. The four groups were formed with a similarity level of $72.74 \%$.

Figure 5. Dendrogram of the $\mathrm{m} / \mathrm{z}$ signals (PS-MS) of the samples A and B from A. chica.

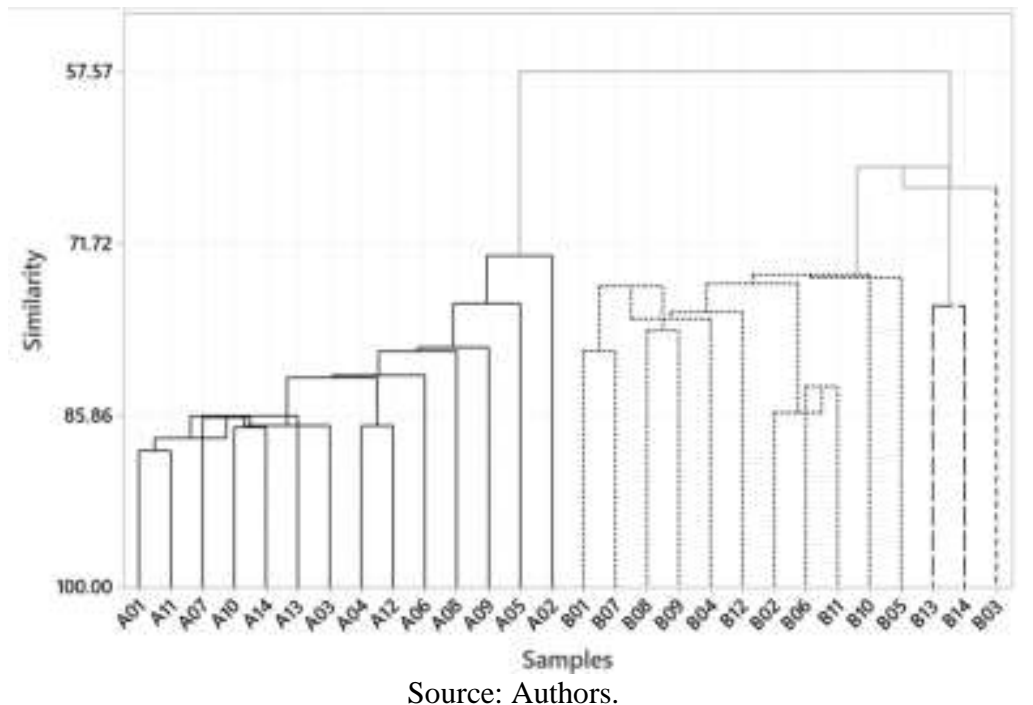

The same pattern of four groups could be seen in the results, considering the 25, 20 or 15 most abundant signals of the mass spectra, while even maintaining the greater homogeneity of samples A. 


\section{Conclusion}

Through the analysis of the mass spectra of the leaf teas of the samples acquired in different commercial establishments in Belo Horizonte, MG, and metropolitan region, it was concluded that the samples were obtained from the species Arrabidaea chica. Being possible to identify, the chemical markers of this species related to the class of substances 3 deoxyanthocyanidins (m/z 285, 299, 301, and 315) were identified.

Significant changes in the $\mathrm{m} / \mathrm{z}$ signals of greater intensity were observed for the different sample reading conditions (24 hours and 15 days after the preparation of the leaf teas). The instability of these classes of substances with time and, consequently, the loss of these active ingredients, which result in changes in the quality and effectiveness of the tea, could be seen. This fact shows that the tea should be used immediately after its preparation.

Ultimately, the experimental data demonstrated that the chemical characterization by PS-MS is a simple, fast, and robust method for the aqueous plant extracts evaluation, having potential for future work on quality analysis and standardization of aqueous extracts of importance to the food, beverage, and agricultural industries, and in the health area.

\section{Acknowledgments}

The authors thank the National Council for Scientific and Technological Development (CNPq, Brazil), and the Coordination for the Improvement of Higher Level Personnel (CAPES, Brazil) for financial support.

\section{References}

Behrens, M. D., Tellis, C. J. M. \& Chagas, M. S. (2012). Arrabidaea chica (Humb. \& Bonpl.) B. Verlot (Bignoniaceae) Revista Fitos, 7, $236-244$.

Cabral, E. C. (2010). Utilização da técnica de fingerprinting por espectrometria de massas para a análise de extratos de produtos naturais. 121f. (Tese Doutorado) - Universidade de São Paulo, São Paulo.

Castañeda-Ovando, A., Pacheco-Hernández, M.L., Páez-Hernández, M.A., Rodríguez, J.A. \& Galán-Vidal, C.A. (2009). Chemical studies of anthocyanins: A review. Food Chemistry, 113(4), 859-871. 10.1016/j.foodchem.2008.09.001.

Deng, J. \& Yang, Y. (2013). Chemical fingerprint analysis for quality assessment and control of Bansha herbal tea using paper spray mass spectrometry. Analytica Chimica Acta, 785, 82-90. 10.1016/j.aca.2013.04.056.

Ferreira, F. A. G., Carvalho, C. M., Costa, J. C. \& Ferreira, J. M. R. (2013). Comprovação do Potencial Medicinal de Arrabidaea chica (Bignoniaceae). Scientia Prima, 01, 15-20.

Ferreira, P. S., Silva, D. F. A., Augusti, R. \& Piccin, E. (2015). Forensic analysis of ballpoint pen inks using paper spray mass spectrometry. Analyst, 140, 811-819. 10.1039/C4AN01617C.

Garret, R., Rezende, C. M. \& Ifa, D. R. (2013). Coffee origin discrimination by paper spray mass spectrometry and direct coffee spray analysis. Analytical Methods, 5, 5944-5948. 10.1039/C3AY41247D.

Hamid, A. M., Jarmusch, A. K., Pirro, V., Pincus, D. H., Clay, B. G., Gervasi, G. \& Cooks, R. G. (2014). Rapid discrimination of bacterias by paper spray mass spectrometry. Analytical Chemistry, 86(15), 7500-7507. 10.1021/ac501254b.

Kalil Filho, A. N., Kalil, G. P. C. \& Luz, A. I. R. (2000). Conservação de germoplasma de plantas aromáticas e medicinais da Amazônia Brasileira para uso humano. MAPA-Embrapa Florestas (Comunicado Técnico), 50, 1-4.

Liu, J., Wang, H., Cooks, R. G. \& Ouyang, Z. (2011). Leaf spray: Direct chemical analysis of plant material and living plants by mass spectrometry. Analytical Chemistry, 83, 7608-7613. 10.1021/ac2020273.

Liu, J., Wang, H., Manicke, N. E., Lin, J. M., Cooks, R. G. \& Ouyang, Z. (2010). Development, characterization, and application of paper spray ionization. Analytical Chemistry, 82 (6), 2463-2471. 10.1021/ac902854g.

Mafioleti, L., Junior Silva, I. F. S., Colodel, E. M., Flach, A. \& Martins, D. T. O. (2013). Evaluation of the toxicity and antimicrobial activity of hydroethanolic extract of Arrabidaea chica (Humb. \& Bonpl.) B. Verl. Journal of Ethnopharmacology, 150 (2), 576-582. 10.1016/j.jep.2013.09.008.

Medeiros, B. J. L., Costa, K. S., Ribeiro, J. F. A., Silva Jr, J. O. C., Barbosa, W. L. R. \& Carvalho, J. C. T. (2011). Liver protective activity of a hydroethanolic extract of Arrabidaea chica (Humb. and Bonpl.) B. Verl. (pariri). Pharmacognosy Research, 3 (2), 79-84. 10.4103/0974-8490.81954.

Oliveira, I. C. A. de (2011). Introdução à Metodologia Cientifica. (3a ed.), Pará de Minas: Virtualbooks, 
Research, Society and Development, v. 10, n. 8, e47410817525, 2021

(CC BY 4.0) | ISSN 2525-3409 | DOI: http://dx.doi.org/10.33448/rsd-v10i8.17525

Schiozer, A. L., Cabral, E. C., Godoy, A. A. F., Chaves, F. C. M., Poppi, R. J., Riveros, J. M., Eberlin, M. N. \& Barata, L. E. S. (2012). Electrospray Ionization Mass Spectrometry Fingerprinting of Extracts of the Leaves of Arrabidaea chica. Journal of Brazilian Chemical Society, 23 (3), $409-414$. $10.1590 / \mathrm{s} 0103-50532012000300006$.

Soparawalla, S. S., Tadjimukhamedov, F. K., Wiley, J. S., Ouyang, Z. \& Cooks, R. G. (2011) In situ analysis of agrochemical residues on fruit using ambiente ionization on a handheld mass spectrometer. Analyst, 136, 4392-4396. 10.1039/C1AN15493A.

Taffarello, D., Jorge, M. P., Sousa, I. M. O. S., Duarte, M. C. T., Figueira, G. M., Queiroz, C. A., Rodrigues, R. A. F., Carvalho, J. E., Goes, A. L. T. R., Riveros, J. M., Eberlin, M. N. \& Cabral, E. C. (2013). Atividade de extratos de Arrabidaea Chica (Humb. \& Bonpl.) Verlot obtidos por processos biotecnológicos sobre a proliferação de fibroblastos e células tumorais humanas. Química Nova, 36, 431-436. 10.1590/S0100-40422013000300014.

Wang, H., Liu, J., Cooks, R. G. \& Ouyang, Z. (2010). Paper spray for Direct Analysis of Complex Mixtures Using Mass Spectrometry. Angewandte Chemie International Edition, 49 (5), 877-880. 10.1002/anie.200906314.

Zhang, Z., Cooks, R. G. \& Ouyang, Z. (2012). Paper spray: a simple and efficient means of analysis of different contaminants in foodstuffs. Analyst, 137, 2556-2558. 10.1039/C2AN35196J.

Zorn, B., Garcia-Piñeres, A. J., Castro, V., Murilo, R., Mora, G. \& Merfort, I. (2001). 3-Desoxyanthocyanidins from Arrabidaea chica. Phytochemistry, 56 (8), 831-835. 10.1016/S0031-9422(01)00038-3. 